\title{
Resource sovereignty and accumulation in the blue economy: the case of seabed mining in Namibia
}

\author{
Rosanna Carver ${ }^{1}$ \\ Lancaster University, United Kingdom
}

\begin{abstract}
Following its global emergence, the blue economy agenda is now touted as a mechanism through which the Republic of Namibia can achieve long-term sustainable and equitable growth. In (re)defining the ocean, seabed mining has been central to these discussions. Drawing on fieldwork and semi-structured interviews undertaken with key actors in Namibia and South Africa, between 2016 and 2017, as well as recent policy debates and discourse surrounding the potential extraction of marine phosphate in Namibia this article critically examines the framing of the marine environment as an extractive space. The blue economy presents opportunities for new forms of capitalist accumulation and this has resulted in struggles over who can accumulate in the marine sphere. This article therefore analyses the emerging and competing claims to sovereignty over this "new" resource frontier, including by state and non-state actors, and identifies which actors have been included or excluded from the blue economy agenda. In discussing sovereignty over this frontier and resources therein, it undertakes a rigorous analysis of the complications created by the ocean as a three-dimensional, voluminous, "borderless" space.
\end{abstract}

Key Words: Namibia, seabed mining, sovereignty, frontier, blue economy, EEZ

\section{Résumé}

Après son émergence à l'échelle mondiale, le programme de l'économie bleue est désormais présenté comme un mécanisme permettant à la République de Namibie de réaliser une croissance durable et équitable à long terme. Dans la (re) définition de l'océan, l'exploitation des fonds marins a été au centre de ces discussions. À l'aide de travaux sur le terrain et d'entretiens semi-structurés menés entre 2016 et 2017 avec des acteurs clés en Namibie et en Afrique du Sud, ainsi que des débats politiques récents concernant le potentiel d'extraction du phosphate marin en Namibie, cet article examine de manière critique le rôle du «espace extractif». S'appuyant sur les récents débats politiques et débats entourant l'extraction potentielle de phosphate marin en Namibie, cet article examine de manière critique le cadrage de l'environnement marin en tant qu'espace d'extraction. L'économie bleue offre de nouvelles possibilités d'accumulation capitaliste, ce qui a entraîné des conflits pour déterminer qui peut s'accumuler dans le monde marin. Cet article analyse donc les revendications de souveraineté émergentes et concurrentes sur cette «nouvelle» frontière de ressources, notamment d'acteurs étatiques et non étatiques, et identifie les acteurs qui ont été inclus ou exclus du programme de l'économie bleue. En discutant de la souveraineté sur cette frontière et des ressources qui s'y trouvent, il entreprend une analyse rigoureuse des complications créées par l'océan en tant qu'espace tridimensionnel, volumineux et «sans frontières».

Mots clés: Namibie, exploitation minière des fonds marins, souveraineté, frontière, économie bleue, ZEE

\section{Resumen}

Tras su surgimiento global, la agenda económica azul es ahora publicada como un mecanismo con el que la República de Namibia puede alcanzar un crecimiento sustentable y equitativo de largo plazo. Al

\footnotetext{
1 Rosanna Carver, Lancaster Environment Centre, Lancaster University, United Kingdom. Email: r. carver "at" lancaster.ac.uk. Acknowledgements: The author would like to thank John Childs and Benjamin Neimark for their comments on earlier drafts as well as the three anonymous reviewers for their helpful feedback. Also, members of the Africa Research Workshop at University of California, Berkeley for their comments and suggestions. This is the third article in John Childs and Christina Hicks (eds.). 2019. "Political ecologies of the blue economy in Africa", Special Section of the Journal of Political Ecology 26: 323-465.
} 
(re)definir el océano, la explotación minera de fondos marinos ha sido central en estas discusiones. Utilizo el trabajo de campo y entrevistas semiestructuradas con actores clave en Namibia y Sudáfrica entre 2016 y 2017, y el análisis de los recientes debates sobre políticas en torno a la posible extracción de fosfato marino en Namibia, para examinar críticamente el marco del entorno marino como "espacio extractivo." Con base en los recientes debates sobre políticas y discursos de la potencial extracción de fosfato marino en Namibia, este artículo hace un examen crítico del marco del ambiente marino como espacio de extracción. La economía azul presenta oportunidades para nuevas formas de acumulación capitalista, lo que ha resultado en una lucha para quienes pueden acumular en la esfera marina. Por lo tanto, este artículo analiza la emergencia y la variedad de demandas de soberanía por parte de actores oficiales y no oficiales, sobre este "nuevo" recurso de la última frontera; además, identifica qué actores han sido incluidos o excluidos de la agenda de la economía azul. En la discusión de la soberanía sobre esta frontera y los recursos que ahí se encuentran, se hace un riguroso análisis de las complicaciones creadas por el océano como un espacio tridimensional, voluminoso y "carente de fronteras."

Palabras clave: Namibia, explotación minera del fondo marino, soberanía, frontera, economía, EEZ

\section{Introduction}

The blue economy is touted as a new mechanism through which states, including the Republic of Namibia $^{2}$, can achieve long-term sustainable and equitable growth. ${ }^{3}$ This follows the global emergence of the blue economy by state and non-state actors looking to tap into the economic potential afforded by the ocean (Silver et al. 2015: 142). The agenda draws on development rhetoric with the aim of addressing the "multiple and overlapping uses in ocean and marine environment" (Winder and Le Heron 2017: 4) and professes to utilise sustainably ocean resources for economic growth without compromising the health of the ecosystem (World Bank 2017a). This spatial reworking of the ocean as a new economic frontier therefore calls for a level of critical engagement with the blue economy and the emergent politics related to sovereignty over resource extraction therein (Winder and Le Heron 2017: 3). Concurrently, seabed mining has become central to discussions of the blue economy in Namibia. Due to the unique upwellings of the Benguela Current Ecosystem - a transboundary ocean current extending, via Namibia, from South Africa in the south to Angola in the north - Namibia is described as a "phosphate factory" (Interview no.1 2017) following the accumulation of rich phosphate deposits over thousands of years (Filippelli 2011: 759). Namibia is now in the process of debating whether to conduct marine mining at greater depths within its Exclusive Economic Zone (EEZ), a position that has attracted significant opposition. As one of the only countries that is considering the possibility of seabed mining, Namibia offers an example of what Jason Moore described as a "commodity-widening strategy" (2010: 291, emphasis in original). Under the shadow of concerns that terrestrial phosphate supplies are depleting ${ }^{4}$ and geopolitical considerations related to the concentration of deposits in Morocco, Western Sahara and China, offshore extraction is being considered in a way that typifies the early stages of how new commodity frontiers are established (see Campling 2012).

This article draws on interviews undertaken by the author in Namibia, in 2016 and 2017. Over a two-year period, in-depth semi-structured interviews took place with key state and non-state actors involved in Namibia's marine space. Interviewees included representatives from the mining and fishing industry, civil society, NGOs and INGOs, ministerial officials and umbrella organizations. These interviews have been analysed along with policy discourse surrounding the potential extraction of marine phosphate in Namibia and critically examines the framing of the marine environment as an extractive space. ${ }^{5}$ While it

\footnotetext{
2 The Republic of Namibia is hereafter referred to simply as Namibia.

3 The Blue Economy has been formalised in the Republic of Namibia's National Development Plan 5: 2017-2022 (NDP5).

${ }^{4}$ However, on shore phosphate could be recycled and used more efficiently.

${ }^{5}$ This article draws on the analysis of policy discourse, including National Development Plans, legislative acts, INGO strategy documents and archival research, which are evaluated in combination with material from 45 semi-structured
} 
has been argued that terrestrial matters should not be applied directly to matters of the sea (Steinberg 2013: 156), the importance of how extraction in the sea conforms to landed conceptions of resource sovereignty is less recognised in current literature. Drawing on critical theories of resource sovereignty, which have a predominantly terrestrial focus, and building particularly on work by Klaus Dodds (2012), Emel et al. (2011) and Ong (2000), this article analyses the emerging and competing claims to sovereignty over this "new" resource frontier, including by capital, state and international actors. As such, this article highlights the dichotomous interpretations mobilised by the state and mining and fishing sectors to support differing agendas and identifies which actors have been included or excluded from the blue economy agenda. ${ }^{6}$

In recognizing that terrestrial epistemologies cannot be directly applied to the marine environment (Dodds 2012; Steinberg and Peters 2015), this article highlights how current discourse in Namibia continues to perceive the ocean through the lens of landed imaginaries, ignoring how the unique nature of the marine environment complicates traditional conceptualizations of resource sovereignty. Rhetoric around these imaginaries also often fails to recognise that the "blue" and "green" economies ${ }^{7}$ do not exist as separate, unconnected entities; rather, they are inextricably interlinked. This is particularly evident in Namibia, where minerals harvested offshore will be "landed" and processed onshore. By discussing sovereignty over this frontier and resources therein, this article therefore bridges the gap between these debates through a rigorous analysis of the complications created by the ocean as a three-dimensional, voluminous, "borderless" space.

In the second section of this article I will discuss the seabed as an extractive frontier more broadly. The third section provides a contextual background to the Namibia case study before considering its marine environment as an (emerging) extractive space and how its physicality has rendered it, incorrectly, as apolitical. This article will then analyse the emerging competing claims to sovereignty, including by the fishing industry, within Namibia's marine sphere.

\section{The seabed as an extractive frontier}

The unique physicality of the marine environment alerts us to new perspectives on theoretical approaches to resource extraction. Resource sovereignty, at least in theory, "translates into both the entitlement and heterogeneous ability of states to pursue environmental and developmental policies within their own territories as they see fit" (Wapner 1998: 276). This notion transposes the concept directly into the economic sphere (Gümplová 2014: 93), a transposition that is particularly evident in the emergence of the blue economy as a new frontier. In its attempt to make the marine environment visible to capital, the blue economy offers a clear example of how sovereignty in the form of "territorially determined resource rights" is being translated to governments. Through theorisations of "exclusive control", these concepts imagine that sovereignty is circumscribed according to territory and that sovereign actors can exert control over their resources free of interference from external relations (Emel et al. 2011). These imaginations, however, blind one to the role of extraneous non-state actors involved in the struggle for, and the allocation and regulation of, resources (Emel et al. 2011: 72). In doing so, they also ignore the role of space which is endogenous to the analysis of interactions between institutions and politics (Bebbington 2013: 16). The unique materiality of the sea leads one to ask how the opening of a new potential resource frontier will impact our understanding of sovereignty. If sovereignty is not perceived to be limited to the confines of territory, and state space is conceptualised as existing on multiple spatial levels (Moiso and Paasi 2013: 257), then the ocean has the potential to further complicate this understanding due its physical and spatial characteristics.

interviews undertaken during the author's fieldwork in Namibia between 2016 and 2017. Interviewees were elite state and non-state actors who are integral to the blue economy and marine phosphate debates in Namibia.

${ }^{6}$ This article positions itself under the third form of political ecology, as articulated by Tetreault (2017). It aims to analyse accumulation strategies with relation to Namibia's marine sphere, identifying who has control over this emerging site of extraction as well as the actors "involved in the institutional and discursive fields of power in which they operate" (Tetreault 2017: 18).

7 The green economy attempts to combine development and conservation visions and is grounded in capitalist logic (Silver et al. 2015. See also Corson and MacDonald 2012; Haas 2012: 95). 
Namibia is a former German colony, and South African mandate territory, prior to its independence in 1990 (Figure 1). Given the historical context of anti-colonialism (Emel et al. 2011: 72), the exercise of sovereignty remained important to post-colonial states following independence, and particularly for African states $^{8}$, with the desire to assert sovereignty over internal natural resources remaining an integral part of nationalist rhetoric (Emel et al. 2011: 71). The expansion of rights based on national sovereignty over marine resources formed an important element of the United Nations Convention on the Law of the Sea (UNCLOS) III negotiations (Adar 1987: 666; Suarez de Vivero 2012), leading to the legal consolidation of EEZs in so far as sovereign rights over resources were assigned to states (Steinberg 2011). However, these rights have not been uniformly assigned, but rather vary so that sovereignty exceeds territory and thereby create a "hybrid maritime state" (Bridge 2014: 5).

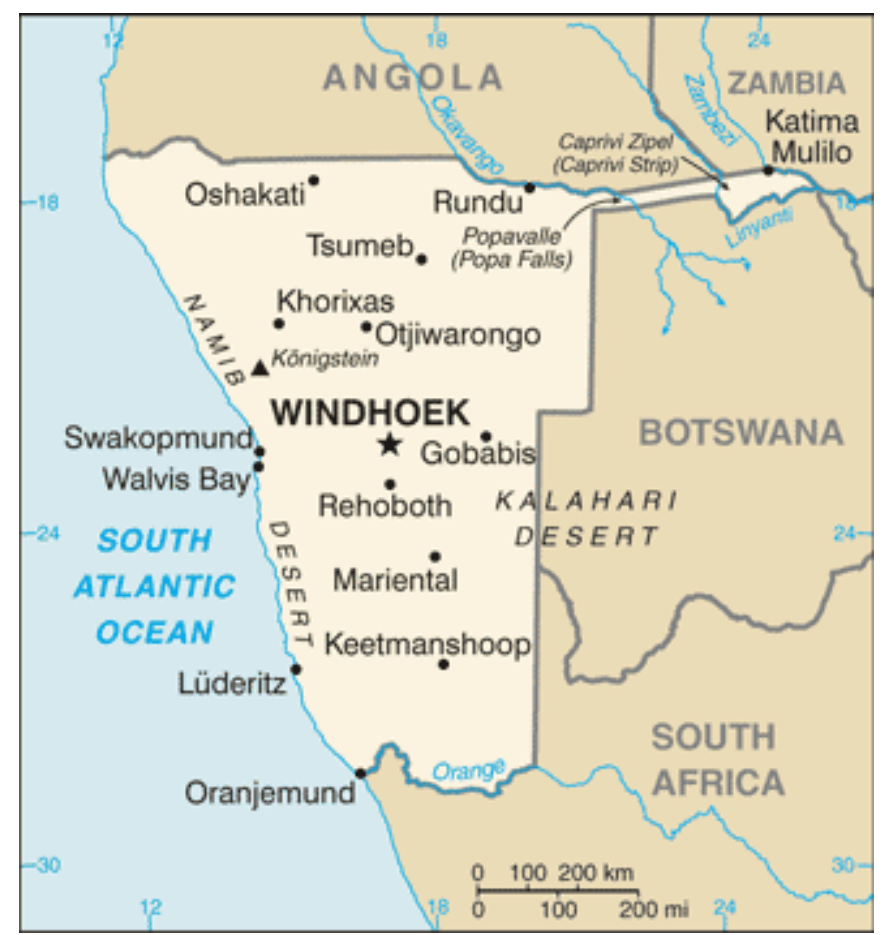

Figure 1: Namibia. Source: The University of Texas (2016).

EEZs are not formalised as "territory" - territorial waters only extend to 12 nautical miles from the baseline of coastal states - but instead different legal regimes are assigned to different aspects of sovereignty. Extending no more than 200 nautical miles from the territorial sea baseline, the EEZ can be understood as a three-dimensional space with three separate, yet interconnected, planes: the surface, the water column and the seabed (and subsoil). These planes comprise of separate legal structures which impact state sovereignty at different spatial levels. The surface has the same conditions as territorial waters where external states have freedom of navigation and the "right of innocent passage" ${ }^{9}$, whereas the coastal state has jurisdiction over the water column and the power to control activities that utilise the marine environment in accordance to their national laws. Finally, the coastal state also holds sovereign rights, rather than sovereignty, over the seabed and its subsoil.

\footnotetext{
${ }^{8}$ Namibia, however, was still a mandated territory at the time of negotiations and was not granted independence until 1990.

${ }^{9}$ As defined by Article 17 of UNCLOS.
} 
Where states have full sovereignty over territorial waters, no other authority can exercise superior rights and absolute ownership is afforded to the state. In the case of the seabed, UNCLOS has utilised the term "sovereign rights" to indicate that the exclusive authority of the state no longer pertains to all activities in the EEZ (ICUN 2012). These rights are solely for the functional purpose of "exploring, exploiting, conserving and managing the natural resources, whether living or non-living", (DOALOS 1982: 43). Africa's maritime domain is characterised by abundant, un(der)exploited natural resources, and as demand for these minerals grows, the economic viability of seabed mining increases (Ramirez-Llodra et al. 2010: 2882; WTO 2010). Simultaneously, there has been recognition of the potential of EEZs to contribute to economic growth (UNECA 2015). This has led to the ocean and the natural resources within this space being conceptualised and commodified under a development "imaginary" (Jessop 2004; Neimark 2016) as part of the blue economy, by international organizations and governments. As such, the importance of control over the sea remains a contemporary issue globally, with submissions for the extension of EEZs according to the extent of state's continental shelves still under negotiation (OLA 2015). However, the discourse used during negotiations on ownership and governance has largely taken the form of an idealised vision of sovereignty, with political leaders articulating ideas associated with national sovereignty in opposition to foreign competitors (Dodds 2012: 993).

The process of seabed mining remains technologically sophisticated and lies (predominantly) in the hands of Western states and multinational corporations. Although the technologies remain under development, mining is projected to occur through a variety of harvesting systems depending on the physicality of the resource being extracted (ISA 2016). These required technologies challenge the idealised vision of sovereignty as, in the case of seabed mining, the ability to exert power relies upon the capability to manipulate volume (Bridge 2010: 56). This exertion of power is exercised through control of the "concession": where corporate actors are attributed the right to accumulate minerals from the seabed (see Bridge 2010 in relation to terrestrial extraction). In the case of marine phosphate, extraction would entail the use of Trailing Suction Hopper Dredgers, a process that extracts sediment from the seabed, moving it through the water column, before transporting the minerals to the shore for beneficiation. While these corporate concessions leave "the state's broader claims to territorial sovereignty" intact, the marine sphere becomes a patchwork of concession holders (see Bridge 2010) that at each stage of extraction are manipulating volume, interacting with the differing interpretations of sovereignty, as detailed above, leading to the potential for contestation.

Resource extraction has the potential to encourage conflict and result in political and economic tensions among foreign investors, governments and citizens (Bebbington 2013; see also Collier and Hoeffler 2005; Le Billon 2001). Through its commodification, nature becomes contested: both as a subject and producer of often unequal social relations associated with and articulated through processes of extraction (Weszkalyns and Richardson 2014; 10, see also Ferguson 2005). To fully understand the governance of extraction and its implications, the spatiality of the resource itself and how these spaces and flows are constructed, valued and governed must be dealt with explicitly (Bebbington 2013: 4; see also Ey and Sherval 2016: 176; Watts 2004: 7). Considered by the African Union to be the "new frontier of African renaissance" (UNECA 2015: 7), the governance of Africa's seas is framed as a technical challenge. Through this the marine environment has been rendered inert, with resources enumerated and ownership assigned, enabling its ingression into the capitalist system (Tsing 2003: 5100). While Anna Tsing's analysis of frontiers ${ }^{10}$ has a terrestrial focus, discourse constructing the ocean (and similarly outer space) as a frontier borrow heavily from landed rhetoric, with little distinction given to the geophysical characteristics that might complicate the governance of the sea and the subsequent ownership and appropriation of the resources therein. On this point, Anna Tsing asks, "how are landscapes made empty and wild so that anyone can come to use and claim them?" (2003: 5101). This question must also be raised in relation to the 'marine scape', and indeed it continually emerges when one analyses the blue economy agenda and the prospective extraction of mineral resources in, and from, Namibia.

${ }^{10}$ Regarded as zones where the "economy, nature and society" collide, frontiers are often characterised by formation of "systems of legality... [conceived] in response to market imperatives" (Barney 2009: 146). 
The concept of the blue economy, like other (predominantly terrestrial) state simplifications, is more fixed and formulaic than the social constructs and practices that it is presumes to represent (Scott 1998: 46). It views the marine environment through "a single optic" (see Scott 1998: 15) ${ }^{11}$, one that is confounded by popular opinion which considers the world's oceans to be "wild" and "empty" (Interview no. 6 2017; Interview no. 9 2017; Interview no.10 2017; Interview no. 26 2016) (see also Steinberg 2011). This is particularly true when looking at discourse referring to portions of Namibia's coasts: "Skeleton coast", for example, conjures in the imagination desolate imagery of an area; a coast that was no more favourably referred to as "the gates of hell" by Portuguese sailors (Jones 2017). In being understood as a frontier, the sea is often imagined to be imperceptible to humans and, therefore, also beyond the scope of the law. ${ }^{12}$ This disconnect, and indicative terminology enables the conceptualisation of any given part of the sea as an alien site of potential (Hannigan 2017: 21) whose value lies in the exploitation of the resources below its visible surface.

\section{The Namibian context}

Before turning to an analysis of the contestations over accumulation in Namibia's marine sphere, it is imperative to consider the context within which these contestations have emerged. Following a period of colonial rule, Namibia became independent in 1990, however the idea of national sovereignty over resources in Namibia emerged initially through the dominance of global capitalism when colonisers attempted to enforce quantitative forms of measurement over areas of territory and resources therein (see Emel et al. 2011: 70). Thus, during colonisation Namibian resources were graduated in accordance to the perceived development status of the Namibian state: Namibia's sovereignty in this context reflected other post-colonial contexts, effectively existing in a "linear continuum" until "they were able to govern themselves" (Chatterjee 1993). Initially a German colony, then-German Southwest Africa ${ }^{13}$ was annexed in 1884 and saw Germany legitimise state territorialisation through extraction (see also Vandergeest and Peluso 1995). This included large-scale foreign exploitation of marine species, including fish, by contract migrant labor (Paterson et al. 2013). The manifestations of German domination were the establishment of bureaucratic boundaries, judicial institutions and the devolution of authority over land as well as other concessions to white settlers (Wallace 2011: 148-149). This concession system enabled the colonial government to grant territory to mining interests (Emel et al. 2011: 73), articulating territories through capital. Following German defeat in the First World War, Namibia was governed, through mandate rule, by South Africa. However, the imposition of German structures in Namibia extended beyond their rule (Melber 2014: 8). Namibia was fractionalized along both race and urban and rural divisions, which were in turn institutionalised to enable the accumulation of capital (Keulder 2000: 74). The mandated coloniser's domestic apartheid policies were administered and entrenched in Namibia (Wallace 2011: 205). Concurrently, Namibia's economy became increasingly intertwined with South Africa's, and Namibia came to be regarded as South Africa's "fifth province" (Silvester 2015); a relationship that remains visible today, articulated through formalised institutions (Du Pisani 2010; Saunders 2016; Wallace 2011: 258) and permeating the national self-imagination, as indicated by interviewees referring to South Africa as both "the mothership" and "our big brother" (Interviews no. 4, 5, 6 and 7, 2017). During mandate rule, mining concessions also migrated from land, with the first offshore diamond mining licence awarded in 1961 (Debmarine Namibia n.d).

Namibia's decolonisation was one of the most prominent of all independence processes in the latter half of the twentieth century, due not least to the involvement of the United Nations (Melber 2014: 8).

\footnotetext{
${ }^{11}$ James Scott uses the example of German scientific forestry to illustrate that, by viewing the forest solely as a provider of commercially viable wood, the environment and its subsequent management was rendered visible to the logic of state (1998: 15).

${ }^{12}$ Due to much of the ocean being out of human sight, the sea is seen as the "ultimate frontier" that also extends beyond the visibility of the law. The historical loss of lives during the slave trade and contemporary deaths of illegalised migrants at sea have been considered as representative of this reality (Heller and Pezzani 2011).

${ }^{13}$ In 1915 Namibia became known as Southwest Africa.
} 
Despite independence being granted in 1990, South Africa continued to claim sovereignty over Walvis Bay, the site of proposed phosphate mining, until 1994 (Wallace 2011: 307). This is due to its strategically and economically important deep-water port. The deep-water port was of naval significance to South Africa and was used to transport mineral wealth, with ownership affording influence over Namibia's economy (Evans 1990). The international agenda was one of decolonisation, not democratisation (Melber 2003). As such, the liberation movement, the South West African People's Organisation (SWAPO), was the only internationally-recognised representative of the Namibian people. Since independence, SWAPO has upheld the heroic nationalist rhetoric its representatives established during the anticolonial struggle, monopolising ownership of the liberation war to provide itself with political legitimacy and a justification for continued hegemonic rule (Malkki 1995; Melber 2014: 26, 2007). This political hegemony has led to Melber's accusation of a blurring of the "boundaries between party, government and state" (Melber 2003). The liberation struggle rhetoric used by SWAPO during the anti-colonial movement, and following independence, speaks of a united Namibia for "all Namibian people" (SWAPO 1976: 39). However, questions remain as to whom these terminologies encapsulate and, to that effect, exclude. High levels of inequality persist, such that Namibia ranks in the top countries for the deepest levels of social disparity and divisions along both racial and class lines (Melber 2007: 111; see also Frayne 2005; Winterfeldt 2002), exacerbated by the legacy of inherent bias in colonial rule (Chatterjee 2014). With disputes over land and accusations ongoing, due to much of productive land remaining in the hands of the white minority and elite capture of resource rents, including from fisheries, questions have recently been raised as to what sovereignty over the ocean as an emerging extractive space would look like (Melber 2014: 92, 103). This is of concern due to the challenges presented by the unique marine environment: the lack of boundaries, the primacy of technologies and the multitude of competing interests that exist in this space. Furthermore, unlike land the sea is very much "out of sight, out of mind" (Interview no. 8 2017); in other words, what happens in the sea is not normally visible, and therefore one cannot easily perceive who interacts with the space and, indeed, who is setting agendas within the environment itself.

\section{Namibia's marine environment as an (emerging) extractive space}

Despite being classified as an upper middle-income country (World Bank 2017b), Namibia maintains some reliance upon donor involvement and grants, particularly during its current financial crisis. At the time of writing Namibia was in recession following economic contraction (Nyaungwa and Winning 2018) with unemployment at $23.3 \%$ (World Bank 2017). However, its transition to upper middle-income status has meant that Namibia is ineligible for many development assistance funds and alternative sources of income are being sought, with one interviewee insinuating that the blue economy initiative is therefore of financial importance, referring to it as "another pot of money" (Interview no. 25 2017). Despite proposals for phosphate mining occurring prior to the formalisation of the blue economy in Namibia's National Development Plan 5 (NDP5), in 2017, the potential for marine mining to contribute to economic development has become central to blue economy discussions in Namibia, and the country is likely to be one of the first to engage in seabed mining. However, in spite of national and pan-continental endorsements, a universal definition of the blue economy remains elusive and this lack of consensus has led to the proliferation of a variety of articulations across competing discourses (Silver et al. 2015). Regardless of the absence of an agreed definition, Namibia's NDP5 claims that the blue economy will ensure the harmonisation of several sectors, including marine mining, as an accelerator for development and sustainable and equitable growth (Republic of Namibia 2017: 24).

Marine mining in Namibia has historically been limited to the dredging of diamonds in the shallows extending from Oranjemund to Lüderitz, which has occurred since the discovery of diamonds in 1907 (Pallet 1995: 84). However, Namibia is now in the process of debating whether to exploit its offshore reserves of phosphate. While onshore extraction of phosphate is preferred due to its comparative simplicity and lower cost, terrestrial deposits are being depleted, leading to an increased interest from international mining companies in these offshore accumulations. Attention has centred on deposits offshore of Walvis Bay and Lüderitz, where the geo-physical nature of the Namibian coastline has meant that a lot of the 
compacting work has already been done for mining companies. As such, these deposits are considered by such companies to be an "easy grab" (Interview no.1 2017).

Despite being articulated as an "easy grab" minerals are not just "packaged" but are physically and socially produced (Childs 2018; Tsing 2003: 5100). Their geophysical properties are essential to understanding how they come into existence and how they are then "made" into resources (see Childs 2018 and Richardson and Weszkalnys 2014). Namibia's ecosystem is predominantly characterised by smaller organisms and fish. Consequently, phosphate is not recycled, and material takes longer to settle than it otherwise would, at depths of 100-800 meters. Due to this inefficiency these phosphate deposits are estimated to be between 20,000 and 100,000 years old. Organic matter including phosphate then settles and is subsequently buried on the sea's subsurface. This sediment then transforms into phosphorite which takes the form of nodules or thick crusts, which are found most abundantly on the continental shelves of SouthWestern African states (Giresse 2007: 245, 259). Deposits will often be between one and two meters thick but there are pockets where more is accumulated, following periods of intense currents. As a result, Namibia's seabed is not smooth: distribution is patchy and can occur over vast areas. There are hills (where more phosphate has accumulated) and pockets and depressions (where no phosphate collects). As such, this potential extractive scape can be divided into discrete concessions where the concession holder is sovereign (Bridge 2010).

Namibian Marine Phosphate Ltd., a joint venture company between the Oman-based Mawarid Mining LLC, and the Namibian company Havana Investments (PTY) Ltd., is developing the world's first marine phosphate project, offshore to the south of Walvis Bay (NMP n.d.). The project, which is situated on Namibia's continental shelf, consists of an area of approximately 2,233 square kilometres (MME 2006). Additional projects are also being considered further south, off shore from Lüderitz. Unlike landed extraction, projects will see marine phosphate move through the different planar levels (the seabed, water column and surface) and associated legal regimes that exist within the EEZ. Trailing suction hopper dredges are proposed to suck ore containing sediment from the seafloor, manipulating the seabed and causing resources to move through space, volume and therefore different legal regimes (also raising environmental concerns in doing so). Phosphate is then processed onshore in plants which in turn can reside outside of a given coastal state's jurisdiction. That these planar levels have separate but interrelated legal structures, as discussed above, will have a corollary impact upon state sovereignty.

While the proposed blue economy agenda attempts to achieve harmonisation between overlapping interests, the project has been met with contention from both internal and external actors. The prospect of offshore phosphate mining in Namibia has been met with controversy from different factions including, but not limited to, formalised civil society, the fishing industry and ministerial representatives. This illustrates how interest in and ownership over the 'marine scape' is not circumscribed. Despite the marine environment often being viewed as an empty space both functionally and in terms of power dynamics, this is far from the case. Concerns that offshore phosphate mining could have environmental implications by damaging sensitive breeding grounds for fish have been raised by the fishing industry, who collectively have historically dominated the marine sphere. These concerns are particularly pertinent as Namibia's fisheries were overexploited during colonial rule (Melber 2014) and policies, which this article will discuss in the subsequent section, have been established in an attempt to redress this exploitation.

Licences for mineral exploitation are currently under negotiation by NMP due to ongoing court cases disputing the validity of their issuance and the allocation of the environmental clearance certificate. ${ }^{14}$ The emerging tensions and territorial disputes over the marine domain have created a situation whereby Namibian fishing industry associations, supported by the company Omualu Fishing, have become embroiled in a related court case. This case has been raised against NMP and the Ministers of Environment and Tourism, Fisheries and Marine Resources and Mines and Energy, targeting the mining licence issued to them and the validity of the environmental clearance certificate they hold (The Namibian 2016). An additional case has been raised against NMP, by a private individual, indicating that articulations of

${ }^{14}$ An 18-month moratorium on marine phosphate mining was imposed place in 2013 but this has been extended and remains in place at the time of writing. 
sovereignty differ between state and non-state actors. Namibia is a case of the articulations of the blue economy and the ways in which differing sovereignty claims over this emerging extractive space are challenged by the nature of the marine environment, as well as the resulting conflicts arising from the desire of different sectors to establish, or continue to exert influence over, the marine domain.

\section{Sovereignty over resources}

As illustrated in Namibia, the deep sea is not at all void (Steinberg 1999: 403), and this has catalysed a desire amongst states to territorialise the sea and exert their sovereignty over its resources through the establishment of EEZs. This process is ongoing as states (including Namibia) are negotiating the delimitation of their EEZs in accordance to the extent of their continental shelves ${ }^{15}$, indicating that territoriality is not static, but rather it is a fluid process (Ellis 2015). The establishment of the EEZs emerged from the desire of predominately developing states to reconcile the "appropriation of nature" within the marine environment (Campling and Colás 2018). By simplifying and codifying the marine environment, through the blue economy, and thus rendering it legible to capital, the marine environment is demystified and is subsequently easier for state actors to manipulate and, therefore, to exploit (see Scott 1998: 15). The desire for legibility is not only held amongst governments: it is sought by prospective mining companies who depend upon divisive techniques to ensure the exclusivity of their licences prior to investing financial capital (Hannigan 2017: 17). The complexity of the 'marine scape' and the multiplicity of actors that interact therein is reduced: thus its "ecological configuration" is ignored until it disappears, only to be rendered visible as an economic resource to manage or exploit (Vandergeest and Peluso 2011: 588; see also Scott 1998: 13). As one INGO worker explained:

[The ocean] is seen an extension of the desert and the only value that comes out of it is fish quotas and oil, if oil was found. I don't think that it is perceived in the same way as terrestrial land is perceived, that there's biodiversity and an ecosystem. I think it is perceived more as a blank space that could make a couple of people rich one day and maybe, by inference, the country wealthier. (Interview no. 11 2017)

However, as with the project of scientific forestry (footnote 11), the oversimplification of the marine environment masks both socio-economic contention and the (geo)political dynamics that exist within this space (Campling and Colás 2018) and opens the state to opposition from society - as seen in Namibia who are looking to "modify, subvert, block and even overturn the categories imposed upon it" (Scott 1998: 49).

While the EEZ acts as an extension to coastal state's jurisdictions, its sovereignty over this space is limited by the geophysical constraints imposed by the environment itself (Campling and Colás 2018). Liam Campling and Alejandro Colás (2018) define EEZs as "terraqueous territories" that separate the political (sovereignty) and economic (property ownership) rights which, Gordon Winder and Richard Le Heron note, enables the remapping of the ocean space as a resource for exploitation (2017: 14). Attempts to harmonise non- state actor's mobility over the seas, with the appropriation of resources therein, is best understood by moving away from traditional "flat" or two-dimensional ontologies to consider the volumetric, three-dimensional space through which resources are circulated and controlled (Bridge 2010).

The complexity of ownership claims described above is exacerbated by the marine environment's fluidity and lack of visible and distinct boundaries. Unlike landed territory where physical boundaries can be erected in the form of walls, signage or fences, the ocean's boundaries exist only as legal constructs that

${ }^{15}$ In 2009 Namibia sought to extend their EEZ in accordance to the outer limit of their extended continental shelf. Their submission claims that Namibia's continental margin extends beyond the $200 \mathrm{~nm}$ from the territorial baseline to encompass a submarine region of 1,062,935.85 $\mathrm{km}^{2}$ (Republic of Namibia 2009: 3). 
are demarcated across the water's surface ${ }^{16}$ These lines do not have geophysical authority but are attached to a juridical system that does (Steinberg 2013: 162). These boundaries have also been shaped by narratives that "coexist and even frequently overlap" (Hannigan 2017: 135). One interviewee elaborated on this point, stating:

In Namibia's ocean space and even on the land adjoining the ocean there seems to be less of a clear definition of who the rights owners are, who are the people who have lived them in the past, do they still have rights in those areas? It's much vaguer. (Interview no.11 2017)

This illustrates that the 'marine scape' is not apolitical; understandings and definitions come from the historical context, the characteristics of the environment itself and the politics shaping it.

The potential of phosphate mining highlights the complexity of the 'marine scape' and the proposed blue economy agenda. The unique nature of phosphate and its extraction exposes conflicting interpretations of the 'marine scape' and its ownership. These interpretations urge observers to look beyond conceptualisations of the marine sphere as a resource space, an interpretation that strips the ocean of the dynamics and articulations of power that are central to understanding how sovereignty is understood and projected. Instead, one is encouraged to view the ocean as an "arena wherein social conflicts occur, and a space shaped by these conflicts" (Steinberg 2001: 20). By analysing the emerging and competing claims to sovereignty over this "new" resource frontier, including by state and non-state actors, the following sections will illustrate the entangled relations that exist within the marine environment. Dichotomous interpretations of sovereignty have been utilised to support differing agendas and identities, in turn including and excluding actors from the blue economy. Often-overlapping claims to sovereignty are complicated by the physical nature of the sea. The ocean's physicality, unlike that of land, means that it holds limited value for human habitation. As such ownership of or control over these spaces has been projected predominantly by interests in state security or (state and non-state) resource extraction. The representation of oceans as empty and wild spaces also renders them empty of social interactions. However, while habitual interest in the oceans is absent, social (re)constructions of the marine sphere are integral to discussions of the blue economy and marine mining and provide the context within which these discursive conflicts occur.

The emerging and competing claims to sovereignty in Namibia's marine sphere will be discussed by firstly focusing on Namibia's fishing industry before analysing state and corporate interpretations. In recognising these competing factions, the following section will also discuss how the blue economy bypasses actors to legitimise accumulation strategies.

\section{Namibia's fishing industry}

Namibia's marine environment encompasses a multiplicity of actors, both state and non-state, who are competing for ownership over the marine domain or the resources that exist in its subsurface. Interactions with and within this space highlight the dynamics and articulations of power that are central to understanding how claims to the 'marine scape' are expressed and how the state balances different industries. Furthermore, emerging, often competing claims to sovereignty highlight that the ocean is far from an empty space and that it cannot be physically or figuratively disjointed from land.

Due to its geophysical composition, Namibia's ocean has been described by key actors to be insular and dominated by a few political actors (Interviews no. 8, 12, 13 2017; Interview no. 27 2016). Definitions of who owns the rights to and ability to accrue rent in the ocean space, and the land adjoining the ocean, are vague. Describing Namibia's blue economy and by extension its marine environment, interviewees representing industry, umbrella organizations and NGOs highlighted that it is the dominion of the fishing industry. Due to the lack of cumulative historical development in the sea, aside from fishing, industries operating within this space have not developed as their equivalents have on land, and those actors who

\footnotetext{
${ }^{16}$ As one interviewee, a Ministerial representative, stated when describing the complications of ownership in the marine
} environment: "you can't put up fences in the ocean." 
already operate offshore are in any case challenged by other potential players agitating for influence in the same space (Interview no. 14 2017). Imaginaries of the sea as a space dominated by fishing activities exclude other claims to the environment. When competing claims in such environments emerge, as seen in Namibia, these spaces become arenas of contestation where conflicts play out (Peluso and Watts 2001). As such, the contestation over marine phosphate has been described as a "basic territorial conflict", one which involves two industry stalwarts (fishing and mining) fighting for ownership of the space; as one business network representative explained: "Fishing is against mining. It is now a case of who is going to win" (Interview no. 12 2017).

Fishing is integral to Namibia's economy (comprising an average of 3.5 percent of Namibia's real GDP) and to its regional and international profile, particularly due to its role as a large employer in the Erongo region (Chiripanhura and Teweldemedhin 2016: 7). Prior to independence the marine environment was subject to (over)exploitation and was described as a "virtually free for all fishing zone" (OECD 2004: 210) and overfishing during the colonial period led to the near depletion of Namibia's fish stocks (Sjösted and Sundström 2015: 80). Following independence, the much-lauded Namibianisation fisheries policies ${ }^{17}$, which sought to ensure that Namibians were the majority shareholders of fishing companies whilst promoting job creation and income generation for the government (Erastus 2002: 43), were heralded as a success story. Namibianisation was initially considered to be indicative of SWAPO's successful management of the country's natural resources (Oelofsen 1999) and enshrined in nationalist rhetoric, as the policy's etymology suggests. Today, fisheries are, in part, celebrated as a national asset (Interview no. 6 2017) and have also been championed as a contributor to food security (Chiripanhura and Teweldemedhin 2016: 7). ${ }^{18}$ The fact that marine mining threatens something so integral to independent Namibia's success has polarised opinions on the matter of phosphate, however.

While there are multiple uses for the 'marine scape', these uses are not attributed equal legitimacy (Winder and Le Heron 2017: 18). These disparate legitimacies have political and economic origins and are attributed weight dependent on factors such as the potential for rent accumulation and the (historical) context(s) under which these uses came into fruition. As seen in Namibia, these factors influence the Namibian states' attribution of weight to different uses in the 'marine scape'. The fishing industry in Namibia has been accused of assuming a "king of the castle" attitude, regarding the 'marine scape' as solely the industry's domain (Interview no. 13 2017). New industries, including marine phosphate mining, directly challenge this and the (perceived) ownership(s) over this space. Indeed, in Namibia's marine environment, according to one interviewee, new entrants are a "clear danger to an old industry" (Interview no. 15 2017). This point is supported by Andrzej Polus and colleagues who, when discussing the potential of exploration for oil reserves in Namibia, warned presciently that while the offshore characteristics of oil concessions and their inability to be looted reduce the potential for conflict over them ${ }^{19}$, conflict could emerge instead between the oil sector and the fishing sector due to the latter's (perceived) integral role in Namibia's economy (2015). The economic potential of phosphate mining has acted as a catalyst for the emergence of this conflict and the Minister of Fisheries and Marine Resources (MFMR), whose ministry holds responsibility for the blue economy as per the NDP5 legislation, has been accused by other ministries, industry actors and (formalised) civil society of possessing "a vested interest and [being] territorial. He sees this as his chiefdom. He is the god of the coastal and marine environment" (Interview no. 16 2017). Here "territory" is framed in a functional manner, indicating how the principles inherent to sovereignty have been translated into the economic sphere: the environment has been made visible through capital, which in turn emphasises the importance of territorial rights.

The potential for phosphate mining clearly indicates that by perceiving the environment through an economic lens, this fluid, three-dimensional space becomes characterised by competing and conflicting

\footnotetext{
17 See Sowman and Cardoso (2010) and Sjöstedt and Sundström (2015) for more information on Namibianisation policies.

${ }^{18}$ Domestic consumption accounted for $10 \%$ of fish harvested. This statistic has been taken from MFMR's 2012-13 Annual Report. This is the most up to date published statistic.

${ }^{19}$ Here, Andrzej Polus and colleagues cite Collier and Hoeffler (2000).
} 
claims. This perception is being challenged in Namibia, with one industry organization representative explaining, "If you divvied things up there will be overlaps in the ocean... Until now everyone has been responsible for their own resource. There are some resources that straddle the borders" (Interview no. 16 2017). Fishing industry representatives argued that they did not want to see "the sea carved up into blocks like it has been on land" (Interview no. 17 2017). However, the marine environment complicates these issues of ownership, its materiality affecting the potential for demarcating these "blocks". Unlike landed extraction, where there is legislation addressing reimbursements when mining licences overlap with agriculturally productive land (Interview no. 18 2017), marine phosphate mining has presented challenges due to its potential impact upon fishermen's quotas which could be impacted due to the mobility of the fish themselves. As aforementioned, the very method of phosphate extraction leads to phosphate passing from the seabed, through the water column, and onto vessels, before being landed, therefore interacting with different legal regimes and ownership claims.

Namibia's marine environment is characterised by an entanglement of both rent and property relations, made explicit through the contestation between fishing and mining (see also Campling and Havice 2014: 722). The unique (geo)physical attributes of the sea, particularly the lack of boundaries create complications. As such, characteristics of marine phosphate and its extraction are important, particularly due to the process's potential interaction with mobile fish resources. The proposed methods of phosphate extraction have met with resistance on environmental grounds. Fears have been raised over the potential environmental destruction it would effect and the subsequent impact it would have upon the habitat of key fish species, particularly due to the dearth of knowledge around how mining will impact on marine ecology and "at which scales, both vertical and horizontal" (Le Meur et al. 2016: 6). Unlike terrestrial mining, the implications of environmental issues are not confined to one location or, indeed, one state; plumes have the potential to circulate sediment through the three-dimensional environment, with impacts moving from the seabed to the water column. While challenges that arise from the mobility of fish between landowners in the marine sphere have been considered (see Campling and Havice 2014: 722), there are concerns from the fishing industry that extraction has the potential to interact with the property rights of fish, challenging and threatening fishing rents. The mobility of fish also brings in external sovereign views and challenges, with the potential to further entangle the sovereign powers of multiple states and non-state actors.

Representatives of Namibia's fishing industry are embroiled in the marine phosphate debate and have been driving rhetoric, by generating media interest and public discussion. They are supported in their efforts by formalised civil society, and particularly by advocacy movements. Capitalistic regimes have been accused of using the oceans as a laboratory (Campling and Colás 2018: 3), something which the aforementioned actors have suggested is occurring in Namibia (Interview no. 4, 14, 17, 19, 20 and 21, 2017). The prospect that phosphate mining may occur at depths where there is a dearth of scientific data or monitoring has raised concerns that the process could impact fish stocks and endanger the fishing industry as well as the wider marine environment. This threat has highlighted the complications that arise due to the transboundary and three-dimensional nature of the space. The disconnect between land and sea has also led actors to argue that concessions are being granted because the sea is understood by both policy makers and industry players as remote, limitless and away from public scrutiny.

The potential environmental effects of phosphate mining have been conceptualised and made visible through discourses around impacts to jobs in the fishing industry. This has been central to discussions on the challenges to the coexistence of the mining and fishing sectors, something that is discussed later in this article in relation to graduated sovereignty. In a time when Namibia has such a high level of income inequality and is simultaneously in recession, this is very emotive for the public. However, proponents of phosphate mining have accused the fishing sector of encouraging an emotional and politically-charged debate. In response to environmental concerns, representatives of the fishing industry are calling for a full, independent and transparent Environmental Impact Assessment process to be undertaken prior to any extraction being allowed to proceed, having raised concerns over the potential bias in EIAs commissioned by the mining industry (Interview no. 10 2017). ${ }^{20}$ The potential of phosphate mining has led to the fishing

\footnotetext{
${ }^{20}$ Concerns raised about the EIA process in Namibia are not limited to phosphate mining nor to the marine environment.
} 
industry's monitoring practices being called into question and has been accused of causing extensive damage to the seabed through bottom trawling (Interview no. 10 2017). As such the industry and the MFMR have been accused of being "holy about the marine environment" (Interview no. 4 2017) in so far as they appear to consider it to be their domain to exploit and damage as they wish, rather than one that they are required to protect. However, there is hope that debates might bring objectivity to current ownership and operations within the EEZ that remain unaddressed following independence and the formalisation of Namibianisation (Interview no. 5 2017).

However, Namibianisation has been criticised and accused of being illusionary (Melber 2003). Promoting Namibian ownership has been challenged; its apparent simplicity complicated by proxy- and cross-ownership, and a lowering of the state's share of resource rents (Kirchner and Leiman 2014; Melber 2003). Namibia's reliance on foreign investment and continued exploitation from external states and industries, under the guise of nationalistic policies, indicates that declaring Namibian sovereignty over resources does not automatically translate into reality. Simultaneously, the presence of nationalistic resource policies does not mean that the extractive space is devoid of extraneous actors (Childs 2016; Emel et al. 2011). Winder and Le Heron indicate that identifying the dynamics and actors involved in fisheries is fraught with difficulty (2017: 11) and as one fishing industry actor stated:

Every country worldwide has a 200-nautical mile [370 kilometres] fishing zone, but, in retrospect you have to ask to who this belongs to in Namibia. I don't think it belongs to Namibians.... I, as a Namibian, don't have a quota. We need to look at the ultimate beneficiary, these are mostly overseas. (Interview no.17 2017)

The latter point highlights concerns that most of the markets exist outside of Namibia. Fieldwork also identified the role of international actors, who have vested interests in Namibia's fishing resources, in influencing the rhetoric applied to phosphate mining. While states have sovereign rights over resources within the seabed, power dynamics effecting extraction operate across different planes, with actors involved in the water column and surface of the environment influencing the politics of the subsoil. These dynamics challenge state sovereignty over its minerals, raising questions as to who is directing property rights and rent in the sea. These questions that are particularly pertinent as the blue economy agenda begins to legitimise new accumulation strategies in Namibia.

\section{One Namibia, one nation? ${ }^{21}$}

As Liam Campling and Elizabeth Havice argue with reference to industrial tuna fisheries in the Global South (2014: 714), state sovereignty has been applied over Namibia's EEZ and the minerals within. As a de facto landlord, the Namibian state can delimit activities and define conditions of production assigning not only fishing licences (see Campling and Havice 2014: 714), but Exclusive Prospecting Licences and Mining Licences to firms for the extraction of marine phosphate. Both activities fall under the auspices of the blue economy remit, which legitimises opportunities for capital accumulation in the marine sphere: opportunities that are shrouded in development rhetoric, which is pertinent given Namibia's current economic situation. However, this has resulted in contestation between factions of capital, over who can accumulate under this remit. While the Namibian state has sovereign rights over its EEZ, this legal form merely indicates the geographic location of ownership and does not account for the fact that the (geo)physical nature of the sea and the socio-economic relations therein affect the methods of appropriation of resources used by either the sovereign state or capitalist firm (Campling and Colás 2018).

When analysing the appropriation of marine mineral resources by the state, the physicality of the marine environment immediately presents challenges over who has access, challenges that will be extended to other operations in the blue economy agenda, as "the marine sector does not have direct accountability.

21 "One Namibia, one nation" was a prominent slogan used during Namibia's postcolonial nation building project. It embodies SWAPO's nationalist discourse and first emerged in the 1970s (Katjavivi 1989: 74-75). 
There's a perception that it is the domain of government and big business and not the domain of ordinary Namibians" (Interview no. 11). Internally, while ministries have been accused of continuing to approach the sea with landed imaginaries ${ }^{22}$, it has been recognised that where technical knowledge about and access to the 'marine scape' exists in Namibia ${ }^{23}$, it is in the hands of the MFMR. Interviewees highlighted that little internal dialogue exists between ministries, which extends to the reciprocity of data (Interview no. 13 2017). As a result, knowledge and, by association, ownership is contained within the MFMR. Concerns were also raised by interviewees over the close involvement of civil servants from the MFMR with advocacy organizations (Interview no. 8 2017; Interviews no.10 and 26, 2016).

For its part, the MFMR is concerned about whose remit monitoring such operations would come under; this is a role belonging traditionally to the Ministry of Environment and Tourism (MET), but it would be taking place in an MFMR-owned space. The ministerial jurisdictions lack coherence when applied to the marine sphere. For example, the MFMR has previously considered the 'marine scape' to be its domain, but responsibility for the issuance of Mining and Exclusive Prospecting Licences belongs to the Ministry of Mines and Energy (MME), whilst Environmental Clearance Certificates are overseen by the MET. This type of fragmentation also raises questions over the policy distinctions between the blue and green economy and the monitoring and management of extractive projects: primarily, where does responsibility for this lie? Levels of state capacity and access are integral to any discussion considering the monitoring of activities in Namibia and more generally across Africa's Maritime Domain. Traditionally discussed in conjunction with or relation to piracy, these considerations are also integral to mineral extraction. In Namibia concerns were raised regarding which ministry (or even whether any part of the state, for that matter) had the capacity and institutional arrangements (including access to boats) to ensure that activities such as phosphate mining are monitored, and that environmental standards are adhered to particularly in a secluded space and at depths that the human eye cannot typically monitor (Le Meur et al. 2016: 3).

The extraction of rent through regimes concerned with socio-ecological "assets", such as those proposed by the blue economy, are produced by establishing and regulating property rights (see Andreucci et al. 2017; Felli 2014). Here the state has a central, and politically informed, role in rent relations (Parenti 2015) and through the institutionalisation of property rights and the delimitation of land or marine space into government sanctioned concessions, rent is extracted (Andreucci et al. 2017: 39). As such, the state effectively becomes the landlord, and de facto owner of its minerals including marine phosphate. The potential extraction of marine phosphate has been shrouded in the discourse of sovereignty, and while the Namibian state has sovereign rights over the resources within its seabed, the precise meaning of this stipulation has been variously interpreted amongst different factions of the Namibian government. The Republic of Namibia's constitution declares that:

...the State shall actively promote and maintain the welfare of the people by adopting, inter alia, policies aimed at the following: (L) maintenance of ecosystems, essential ecological processes and biological diversity of Namibia and utilization of living natural resources on a sustainable basis for the benefit of all Namibians, both present and future. (The Republic of Namibia 1998: 46)

Similarly, Namibia's Minerals Policy states that "The Ministry of Mines and Energy facilitates and regulates the responsible development of the minerals sector for the benefit of all Namibians" (The Ministry of Mines and Energy). However, several interviewees highlighted that dichotomous interpretations of sovereignty existed even at state level. For instance, the abovementioned issue of differing interpretations of the constitution was exemplified where different ministries read the stipulation "for the benefit of all

22 The Ministry of Environment and Tourism (MET) for example is responsible for issuing environmental clearances despite being predominantly terrestrially focused with a dearth of marine scientists who in turn operate within MFMR. Interview, Environmental Consultant, Windhoek, 2017.

${ }^{23}$ It is important to note that scientific knowledge, pertaining to the marine sphere, also resides externally to Namibia. 
Namibians" in antithetical ways to support their own agendas. This in turn has been exacerbated by marine phosphate mining. One interviewee explained: "The MME is using the constitution to back up their plans to mine [marine phosphate] for the benefit of all Namibians. The MFMR are using the same quote against this (Interview no. 10 2017)." Interviewees also challenged the notion of the state acting "for the benefit of all Namibians", including future generations, questioning who benefitted from Namibia's resources and who would benefit from the proposed marine phosphate mining developments in future.

The Namibian state's actions have yet to reflect SWAPO's rhetoric that resources will be utilised for the benefit of "all Namibians", not least given that post-independence development has enabled the growth of a "parasitic class" that has come to appropriate public resources (Melber 2015). Despite being viewed internationally as a bastion for transparency in the extractive industry in Africa, Namibia's management of its mineral resources has been referred to as "opaque and vague" (Polus et al. 2015: 44). Given the blurring between the party and the state, concerns have been raised over the inevitability of "endemic corruption" in Namibia (Grobler 2014; see also Weylandt 2017) and the government has been accused of continuing the "exploitative and discriminatory nature of the century of firm occupation under German and South African settler colonialism" (Melber 2007: 110). The need to ensure that Namibian ownership was central to any negotiations was highlighted:

When you go back again to the history of Namibia, in terms of apartheid, one should understand the fact that we couldn't enjoy permanent sovereignty over [our] natural resources... Resources of a country should be used in a way to benefit the collective population, not only a minority or elite group (Interview no. 23 2017).

Interviewees indicated that immediately following independence, Namibians viewed government policies as progressive and able to address these systemic inequalities. However, as one NGO worker explained, the government has now become a centralised and monolithic behemoth that has allowed the capture of resource rents by elites (Interview no. 11 2017, see also Melber 2014).

While rent appropriation from marine phosphate is considered to be in the interest of the nation, this assumption must be interrogated. Where state ownership over resources does exist, the strategy of developmental states "are not uniform across the national territory" and it is this gradation of sovereignty and citizenship that enables states to capitalise on global and local opportunities (Ong 2006: 72, 77). This distortion has masked the interests of communities, which in turn remain unaddressed (Melber 2014). The perceived disconnect between communities and the marine environment has exacerbated this, with administrative decisions being made under the assumption that the marine environment is empty of social actors and dynamics. Agendas, such as 'blue growth' present opportunities and legitimisation for extraction, that further enable the state and corporations to circumvent these actors. Just as Aihwa Ong describes in her work on variegated sovereignty, sovereignty is not a "container concept" but is instead the result of administrative decisions which lead states to deploy sovereignty in a flexible manner (Ong 2006: 70). This gradation of sovereignty can be utilised by state governments to legitimise their policies (Dodd 2012: 993; Elden 2009) but can additionally provide opportunities for political elites to accrue rent. While Namibian ownership of the phosphate mining project has been highlighted, a 15\% stake has been attributed to an individual that interviewees described as a well-known "tenderpreneur." A tenderpreneur (a portmanteau of "tendering" and "entrepreneur") is a phrase used in Southern Africa to describe an individual who utilizes their political influence to secure tenders and contracts (see also Beresford 2015). As such, dissatisfaction has been expressed by Namibians around the uneven distribution of resource rents due to uncertainty as to who really benefits from the concept of "Namibian ownership" (Interview no. 11 2017).

The increasing mobility of capital challenges the ontological containment of states and their societies within sovereign space. This, alongside the failure to recognise role of temporal conditions has created a kind of "territorial trap" (Agnew 1994: 77). While this article has discussed the role of international companies who operate within the fishing industry, it is also important to consider the role of the (potential) phosphate concession holder(s) and their interactions with the local context (Snyder and Bhavani 2005; 
Watts 2004). National sovereignty is often expressed as existing in opposition to foreign capital (Emel et al. 2011), for example in the case of the nationalisation of resources in Namibia on land and questions of ownership that have emerged from the potential of phosphate mining. Justifying the creation of the stateowned mining company Epangelo, and the declaration of coal, copper, diamonds, gold, rare earth metals and uranium as strategic minerals, former Minister of Mines and Energy, Isak Katali drew on injustices experienced during colonialism and stated that Namibia had become an "Eldorado of speculators and other quick fix, would-be mineral explorers and mining developers... dominated by foreign multinational corporations" (2011). The contestation surrounding rent can also be linked to historic conditions (Campling and Havice 2014: 720) and Namibia's unique colonial history has presented challenges to sovereign rights and its control of rents. While the state has been positioned as an "abstract landlord" of the now independent Namibian territory, there remain substantive similarities between colonial and contemporaneous relations regarding issues of "sovereignty, territory and mineral resources" (Emel et al. 2011: 77; see also Nii Botchway 1998). The question is therefore not whether the state has sovereignty but how this is made legible to enable extractive industries to interact with, and ultimately extract resources from, these "sovereign territories" (Emel et al. 2011: 77) or, in the case of offshore mining, spaces with articulations of sovereign rights.

While foreign direct investment (FDI) and national sovereignty might initially appear to be antagonistic, the very concept of FDI cannot exist without national sovereignty (Emel et al. 2011: 77). Although the EEZ acts as a legal enclosure to enable states to accrue rent from offshore mineral extraction, the unique geophysical characteristics of the 'marine scape' also expose the limits to the imposition of concepts of territorial sovereignty from land onto resource extraction in the sea. As such, despite the state remaining a key actor, there remains reliance upon external actors to enable exploitation of marine phosphate and power imbalances remain. Unlike in the instances of some land-based frontiers, the prospectors involved in marine mining are not "gold diggers" (Emel et al. 2011), but multinational corporations that can achieve the requirement of capital and technology, further exacerbating the reliance on FDI for exploitation of sovereign resources for profit (Interviews no. 4, 24 and 25 2017). These enclave economies are therefore simultaneously integrated into the "global economy and fragmented from national space" (Bridge 2015), contradicting traditional imaginations of the "nation" (Bridge 2010; Watts 2003). Interviewees also challenged the involvement of the international companies in their 'marine scape', arguing that they did not want their EEZ to be a "guinea pig" (Interviews no. 4, 14 17, 19, 20, and 21 2017), a space for other states to test their technology. They voiced concerns that other states were not considering exploitation in their own EEZs, due to their fear of environmental damage occurring, but under the guise of development are using Namibia as a laboratory. These concerns contradict the stance African states took during UNCLOS negotiations, proposing that formalisation of EEZs would enable states to safeguard their resources to avoid exploitation as experienced onshore (see also Egede 2011).

The integration of "enclave economics" into the global economy highlights the blurring between the blue and the green economy. Current policy in Namibia fails to recognise that the "blue" and "green" do not exist as separate, unconnected entities; rather, they are conjoined. While it is important to recognise the distinctive characteristics of the 'marine scape', it is essential to recognise that these distinctions do not "untie" the littoral state from the sea. This is particularly evident in Namibia in which minerals harvested offshore are dependent on "landed" infrastructure for processing onshore (Campling and Colás 2018) challenging the idea of where the marine environment begins and ends (see also M'Gonigle and Dempsey 2003). Extractive industries are commonly characterised by a sharp disconnect between production and the local population, where neither the resource nor the money related to it touch a state's landed territory (Ferguson 2005: 378). This is particularly evident with marine resources which depend on marketability rather than direct consumption. Although rhetoric suggests that Namibia's use of phosphate is primarily for agricultural purposes, thus contributing to food security, those doubting this position have suggested that the majority will be used for export. Ferguson argues that although contemporary investment in mineral extraction in Africa has been territorialized it has minimal economic benefit to the wider population (2005: 378). Resource flows are replicated in the labor, structures and technologies required to extract (Campling and Colás 2018). This is evident in Namibia, where despite industry rhetoric attempting to promote the idea 
that marine phosphate has the potential to contribute to employment local individuals are unlikely to be involved. Though NMP and the MET argue that marine phosphate could provide up to 1,000 jobs, (Interview no. 12017$)^{24}$ civil society, consultants and industry umbrella organizations argued that this number was over-inflated, and biased towards low-skilled roles (Interviews no. 13, 17 and 22 2017). This is due to the complexity of the operation, exacerbated by the offshore nature of extraction. Extraction will occur from vessels, requiring specific technical skills, which contributes to the likelihood that the industry will import much of its equipment and technical labor.

The headquarters of multinational corporations involved in marine phosphate discourse are external to Namibian territory and this economic and political logic offers "a clear contrast to [James] Scott's theorisation of a rational, grid like developmental state" (Ferguson 2005: 378-379; see also Scott 1998). Unlike Scott's conceptualisation of a continuous national grid, the "usable" (Ferguson 2005: 380) areas of Namibia's marine environment will effectively be divided as exclusive sites of extraction. These enclaves are then linked into transnational networks, in terms of trade and private governance (Ferguson 2005) with the headquarters of previously interested Joint Venture Corporations located in Australia, Oman and Israel. Additionally, seabed resources will be subject to "enclaving" given that extraction occurs offshore with resources landed only for the refining process. This process may take place on a state's terrestrial territory ${ }^{25}$ but could also bypass landed territory altogether to be taken to plants within other state jurisdictions. As such, these "useful" enclaves become secured and "governed through private or semi-private means" and unlike the continuous and standardised constructs of the state, enable capital to "hop" rather than flow (Ferguson 2005: 380). These networks thereby enable capital, such as phosphate, to bypass "contiguous geographical space" whilst avoiding the nation-state's grids of legibility that characterise Scott's theorisations (2005: 379).

As illustrated, the Namibian state is not the sole agent of rent within its EEZ. It is also involved in mediating domestic and foreign interests (see also Campling and Havice 2014: 715): interests which are confounded through legitimizing agendas of accumulation, such as the blue economy. Historically, capitalist engagement and appropriation within Namibia's marine sphere has been incongruous, and often contradictory to the concept of national sovereignty (see Andreucci et al. 2017 for similar arguments). The potential for marine phosphate mining in Namibia has also been influenced by advances in technology as well as shifts in geopolitical and economic logic. The blue economy agenda, which sees the "governance of circulation [shift] away from the nation-state" (Chalfin 2018; Easterling 2014), offers legitimisation of new accumulation strategies and attracts investment that can also exploit gaps in regulatory space (see also Chalfin 2018). Given Namibia's current economic climate, the blue economy appears to offer a multitude of development opportunities. However, as illustrated, its EEZ is far from being an empty space that can be simply divided with rights assigned to new entrants. Political and economic realities are shaping contestations over the potential to accumulate: contestations which are exacerbated by the marine sphere's (geo)physical characteristics.

\section{Conclusion}

The emergence of the blue economy rhetoric has resulted in a lack of engagement with political interests over the 'marine scape' and resources therein that exist internally and externally to the state (Phillips et al. 2016: 27), as well as which actors have agency over policy design and implementation. It is these interests that ultimately influence resource extraction and the production of the extractive space itself. The potential of phosphate mining has been credited in Namibia with highlighting the complexity of the 'marine scape' which has become inextricably linked to the blue economy agenda. The unique nature of phosphate and its extraction exposes conflicting interpretations of the 'marine scape' and ownership over it, resulting in multiple and often dichotomous interpretations of sovereignty existing even at state level. These

${ }^{24}$ NMP claim that during phase 1 of the planned operation (production of phosphate rock) approximately 150 permanent new jobs will be created with 400-500 additional people employed during the development construction phase and 300 indirect employment opportunities through the requirement for support services (NMP n.d.).

${ }^{25}$ As proposed by NMP. 
interpretations have been mobilised by the state and mining and fishing sectors to support differing agendas. Interest in Namibia's EEZ, blue economy and resources therein extends beyond the economic and technical. Like the "Saving the Ocean" discourse, which Hannigan argues has a centrality to positive reactions with recent Marine Protected Areas, the blue economy and subsequent zonation of the ocean appeals to governments as it circumvents the politics of groups with environmental concerns (2017: 131). By circumventing the groups involved, power remains in the hands of others. That Namibia's current economic situation and reliance on donor involvement are associated with its formalisation of the blue economy, raises questions not only around the ownership of the concept, but by association, ownership of the space itself.

In fetishising the idea of national sovereignty over resources, the influence of international instruments and organizations over the governance of resources is overlooked (Miller 1995: 101-103). As illustrated, Namibia's blue economy works to justify international involvement that can supersede the state. While, as the Namibian case illustrates, the blue economy presents opportunities for new forms of capitalist accumulation, this has resulted in struggles over who can accumulate in the marine sphere. These struggles bring to the fore political and economic realities that are shaping these contentions, particularly with regards to Namibia's fishing industry. Additionally, the exercise of scientific authority in rendering the sea legible has implications on both the social and political highlighting the importance of understanding the power dynamics embedded in the articulation of space and its management (see Silver et al. 2015). The complexity of this space and the dynamics that this article has demonstrated allow us to consider the varying articulations of power that in turn are central to understanding how sovereignty over the 'marine scape' is projected.

\section{References}

Adar, K. 1987. A note on the role of African states in committee I of UNCLOS III. Ocean Development and International Law 18(6): 665-681.

Agnew, J. 1994. The territorial trap: The geographical assumptions of international relations theory. Review of International Political Economy 1(1): 53-80.

Andreucci, D., M. García-Lamarca, J. Wedekind and E. Swyngedouw. 2017. "Value Grabbing": a political ecology of rent. Capitalism Nature Socialism 28(3): 28-47.

Bebbington, A.J. 2013. Natural resource extraction and the possibilities of inclusive development: politics across space and time. ESID Working Paper No. 21: 1-41.

Barney, K. 2009. Laos and the making of a 'relational' resource frontier. Re-thinking Frontiers in Southeast Asia 175(2): 146-159.

Beresford, A. 2015. Power, patronage, and gatekeeper politics in South Africa, African Affairs 114(455): 226-248.

Bridge, G. 2010. The Hole World: scales and spaces of extraction. New Geographies 2: 43-48.

Bridge, G. 2014. Resource geographies II. Progress in Human Geography 38(1): 118-130.

Bridge, G. 2015. The Hole World: scales and spaces of extraction. Scenario 05. (version of Bridge 2010)

Campling, L. 2012. The Tuna "commodity frontier": business strategies and environment in the industrial tuna fisheries of the Western Indian Ocean. Journal of Agrarian Change 12(2-3): 252-278.

Campling, L and A. Colás. 2018. Capitalism and the sea: sovereignty, territory and appropriation in the global ocean. Environment and Planning D: Society and Space 36(4): 776-794.

Campling, L and E. Havice. 2014. The problem of property in industrial fisheries. Journal of Peasant Studies 41(5): 707-727.

Chalfin, B. 2018 in press. On-shore, off-shore Takoradi: terraqueous urbanism, logistics, and oil governance in Ghana. Environment and Planning D: Society and Space. https://doi.org/10.1177/0263775818800720 
Chatterjee, P. 1993. Nationalist thought and the colonial world: a derivative discourse. Minneapolis: University of Minnesota Press.

Chatterjee, P., T. Guha-Thakurta and K. Bodhisattva (eds.). 2014. New cultural histories of India: materiality and practices. Oxford: Oxford University Press.

Childs, J. 2016. Geography and resource nationalism: a critical review and reframing. The Extractive Industries and Society 3(2): 539-546.

Childs, J. 2018 in press. Extraction in four dimensions: time, space and the emerging geo(-)politics of deep sea mining. Geopolitics https://doi.org/10.1080/14650045.2018.1465041

Chiripanhura, B and M. Teweldemedhin. 2016. An analysis of the fishing industry in Namibia: the structure, performance, challenges, and prospects for growth and diversification. Washington, D.C.: International Food Policy Research Institute.

Capps, G. 2016. Tribal-landed property: the value of the chieftaincy in contemporary Africa. Journal of Agrarian Change 16(3): 452-477.

Collier, P. and A. Hoeffler. 2005. Resource rents, governance, and conflict. Journal of Conflict Resolution 49(4): 625-633.

Corson, C. and K. MacDonald. 2012. Enclosing the global commons: the Convention on Biological Diversity and green grabbing. Journal of Peasant Studies 39: 263-283.

Debmarine Namibia. n.d. Our history [accessed May 2 2018]. https://debmarinenamibia.com/main/ourhistory

Dodds, K. 2012. Graduated and paternal sovereignty: Stephen Harper, Operation Nanook 10, and the Canadian Arctic. Environment and Planning D: Society and Space 30(6): 989-1010.

Division for Ocean Affairs and the Law of the Sea. 1982. Submissions, through the Secretary-General of the United Nations, to the Commission on the Limits of the Continental Shelf, pursuant to article 76, paragraph 8, of the United Nations Convention on the Law of the Sea of 10 December 1982', United Nations, 7 March [accessed 16 May 2018], available from: http://www.un.org/Depts/los/clcs_new/commission_submissions.htm.

Du Pisani, A. (ed.). 2010. State, society and democracy: a reader in Namibian politics. Macmillan Education.

Easterling, K. 2014. Extrastatecraft: the power of infrastructure space. London: Verso.

Edwards, M. 2004. Civil society. Cambridge: Polity Press.

Egede, E. 2011. African states and the evolution of the regime of the area and the common heritage of mankind. In Egede, E. (ed.) Africa and the deep seabed regime: politics and international law of the common heritage of mankind. Berlin: Springer. Pp. 1-30.

Ellis, M.H. 2015. Over the borderline? Rethinking territoriality at the margins of empire and nation in the modern Middle East (part I). History Compass 13(8): 411-422.

Emel, J., M. Huber and H. Makenea. 2011. Extracting sovereignty: capital, territory, and gold mining in Tanzania. Political Geography 30(2): 70-79.

Erastus, A.N. 2002. The development of the Namibianisation policy in the hake subsector, 1994-1999. NEPRU Working Paper 82. Namibia: NEPRU.

Evans, G. 1990. Walvis Bay - South Africa, Namibia and the question of sovereignty. International Affairs 66(3): 559-568.

Ey, M. and M. Sherval. 2016. Exploring the minescape: engaging with the complexity of the extractive sector. Area 48(2): 176-182.

Felli, R. 2014. On climate rent. Historical Materialism 22 (3-4): 251-280.

Ferguson, J. 2005. Seeing like an oil company: space, security, and global capital in neoliberal Africa. American Anthropologist 107(3): 377-382.

Filippelli, G.M. 2011. Phosphate rock formation and marine phosphorus geochemistry: the deep time perspective. Chemosphere 84(6): 759-766. 
Frayne, B. 2005. Eating away from home: rural productivity and urban survival in Namibia. Journal of Contemporary African Studies 23(1): 51-76.

Giresse, P. 2007. Tropical and sub-tropical West Africa - marine and continental changes during the Late Quaternary. Elsevier.

Grobler, J. 2014. Namibia slipping into endemic corruption. Al Jazeera [accessed May 22 2018]. www.aljazeera.com/news/africa/2014/09/namibia-slipping-into-endemic-corruption201492131519733850.html.

Gümplová, P. 2014. Restraining permanent sovereignty over natural resources. Enrahonar. Quaderns de Filosofia (53): 93-114.

Haas, P.M. 2012. The political economy of ecology: prospects for transforming the world economy at Rio + 20. Global Policy 3(1): 94-101.

Hannigan, J. 2016. The geopolitics of deep oceans. Cambridge: Polity.

Heller, C and L. Pezzani. 2011. The left-to-die boat. The deadly drift of a migrants' boat in the Central Mediterranean [accessed April 29 2018]. https://www.forensic-architecture.org/case/left-die-boat/ 26 March 2018.

IUCN. 2012. Sovereignty and sovereign rights [accessed April 20 2018]. https://www.iucn.org/content/sovereignty-and-sovereign-rights.

Jessop, B. 2004. Critical semiotic analysis and cultural political economy. Critical Discourse Studies 1(2): 159-174.

Jones, J.J. 2017. On desolate sands: beached shipwrecks in the Namibian coastal landscape. In Harris, L. (ed.). Sea ports and sea power. Springer. Pp. 89-100.

Keane, J. 1998. Civil society: old images, new visions. Stanford: Stanford University Press.

Keulder, C. 2000. State, society, and democracy: a reader in Namibian politics. Windhoek: Gamsberg Macmillan.

Kirchner, C. and A. Leiman. 2014. Resource rents and resource management policies in Namibia's postIndependence hake fishery. Maritime Studies 13(1): 1-23.

Le Billion, P. 2001. Angola's political economy of war: the role of oil and diamonds, 1975-2000. African Affairs 100(398): 55-80.

Le Meur, P., N. Arndt, P. Christmann and V. Geronimi. 2016. Deep-sea mining prospects in French Polynesia: governance and the politics of time. Marine Policy 95: 380-387.

M'Gonigle, M. and J. Dempsey. 2003. Ecological innovation in an age of bureaucratic closure: the case of the global forest. Studies in Political Economy 70: 97-124.

Malkki, L. 1995. Purity and exile: violence, memory and national cosmology among Hutu refugees in Tanzania. Chicago: University of Chicago Press.

Melber, H. 2003. From controlled change to changed control: the case of Namibia. Journal of Contemporary African Studies 21(2): 267-284.

Melber, H. 2007. Transitions in Namibia: which changes for whom? Stockholm: Nordiska Afrikainstitutet.

Melber, H. 2014. Understanding Namibia: the trials of independence. London: C. Hurst \& Co.

Melber, H. 2015. Post-liberation democratic authoritarianism: the case of Namibia. Politikon 42(1): 45-66.

Miller, C. 2005. The design and management of international scientific assessments: lessons from the climate regime in A.E. Farrell and J. Jäger (eds.). Assessments of regional and global environmental risks: designing processes for the effective use of science in decision-making. London: Routledge. Pp. 187-205.

MME. 2006. Namibia Mining Cadastre Portal [accessed May 10 2018] https://maps.landfolio.com/Namibia/.

Moisio, S. and A. Paasi. 2013. Beyond state-centricity: geopolitics of changing state spaces. Geopolitics 18(2): 255-266. 
Moore, J.W. 2010. "Amsterdam is standing on Norway" Part II: the global North Atlantic in the ecological revolution of the long seventeenth century. Journal of Agrarian Change 10 (2): 188-227.

Neimark, B. 2016. Biofuel imaginaries: the emerging politics surrounding 'inclusive' private sector development in Madagascar. Journal of Rural Studies 45: 146-156.

Nii Botchway, F. 1998. Land ownership and responsibility for the mining environment in Ghana. Natural Resources Journal 38(4): 509-536.

NMP (n.d) Namibian Marine Phosphate FAQs [accessed March 26 2018]. http://www.namphos.com/home/faqs/item/98-namibian-marine-phosphate-faqs.html.

Nyaungwa, N. and A. Winning. 2018. UPDATE 1-Namibia drops into recession as construction, retail slump [accessed March 29 2018]. https://www.reuters.com/article/namibia-gdp/update-1-namibiadrops-into-recession-as-construction-retail-slump-idUSL8N1RB2FO.

Oelofsen, B.W. 1999. Fisheries management: the Namibian approach. ICES Journal of Marine Science 56: 999-1004.

OLA. 2015. Submissions, through the Secretary-General of the United Nations, to the Commission on the Limits of the Continental Shelf. Article 76: paragraph 8. The United Nations Convention on the Law of the Sea.

Ong, A. 2000. Graduated sovereignty in South-East Asia. Theory, Culture \& Society 17(4): 55-75.

Pallet, J. 1995. The Sperrgebiet, Namibia's least known wilderness. Windhoek: Desert Research Foundation of Namibia and Namdeb.

Paterson, B., C. Kirchner and R.E. Ommer. 2013. A short history of the Namibian hake fishery-a socialecological analysis. Ecology and Society 18(4): 66.

Peluso, N. and M.J. Watts (eds.). 2001. Violent environments. Ithaca: Cornell University Press.

Phillips, J., E. Hailwood and A. Brooks.2015. Sovereignty, the 'resource curse' and the limits of good governance: a political economy of oil in Ghana. Review of African Political Economy 43(147): 117.

Polus, A., D. Kopinski and W. Tycholiz. 2015. Ready or not: Namibia as a potentially successful oil producer. Africa Spectrum 50(2): 31-55.

Ramirez-Llodra. E., A. Brandt, R. Danovaro, B. De Mol, E. Escobar, C.R. German and M. Vecchione. 2010. Deep, diverse and definitely different: unique attributes of the world's largest ecosystem. Biogeosciences 7(9): 2851-2899.

Republic of Namibia. 2017. Namibia's 5th National Development Plan. Namibia [accessed May 29 2018]. http://www.gov.na/documents/10181/14226/NDP+5/5a0620ab-4f8f-4606-a449-

ea0c810898cc?version=1.0.

Republic of Namibia. 2009. Continental Shelf Submission of Namibia. Executive Summary [accessed May 29 2018].

http://www.un.org/Depts/los/clcs_new/submissions_files/submission_nam_50_2009.htm.

Richardson, T. and G. Weszkalnys. 2014. Introduction: resource materialities. Anthropological Quarterly 87(1): 5-30.

Saunders, C. 2016. South Africa and Namibia: aspects of a relationship, historical and contemporary. South African Journal of International Affairs 23(3): 347-364.

Scott, J. 1998. Seeing like a state: how certain schemes to improve the human condition have failed. New Haven: Yale University Press.

Silver, J., N. Gray, L. Campbell, L. Fairbanks and R. Gruby. 2015. Blue economy and competing discourses in international oceans governance. The Journal of Environment and Development 24(2): 135-160.

Silvester, J. 2015. Forging the Fifth Province. Journal of Southern African Studies 41(3): 505-518.

Sjöstedt, M. and A. Sundström. 2015. Coping with illegal fishing: an institutional account of success and failure in Namibia and South Africa. Biological Conservation 189: 78-85. 
Snyder, R. and R. Bhavnani. 2005. Diamonds, blood, and taxes. Journal of Conflict Resolution 49(4): 563597.

Steinberg, P. 1999. Navigating to multiple horizons: toward a geography of ocean-space. Professional Geographer 51(3): 366-375.

Steinberg, P. 2001. The social construction of the ocean. Cambridge: Cambridge University Press.

Steinberg P. 2013. Of other seas: metaphors and materialities in maritime regions. Atlantic Studies 10(2): 156-169.

Steinberg, P. and K. Peters. 2015. Wet ontologies, fluid spaces: giving depth to volume through oceanic thinking. Environment and Planning D: Society and Space 33(2): 247-264.

Suárez-de Vivero, J.L. 2012. The extended continental shelf: a geographical perspective of article 76 of the implementation of article 76 of UNCLOS. Ocean and Coastal Management 73: 113-126.

SWAPO. 1976. The Constitution and the Political Program. Political Program of the South West Africa People's Organisation (SWAPO) of Namibia. Adapted by the Meeting of the Central Committee. SWAPO Department for Publicity \& Information. Lusaka: Zambia.

Tetreault, D. 2017. Three forms of political ecology. Ethics and the Environment 22(2): 1-23.

The Republic of Namibia.1998. The Namibian Constitution. Article 95. Promotion of the Welfare of the People: 46.

The Namibian. 2016. Four file case against phosphate licence [accessed April 2 2018]. https:/www.namibian.com.na/157681/archive-read/Four-file-case-against-phosphate-licence.

Tsing, A. 2003. Natural resources and capitalist frontiers. Economic and Political Weekly 38(48): 51005106.

UNECA. 2015. Africa's blue economy: a policy handbook. Ethiopia: Economic Commission for Africa.

Vandergeest, P. and N.L. Peluso. 1995. Territorialization and state power in Thailand. Theory and Society 35: 385-426.

Wallace, M. 2011. A history of Namibia: from the beginning to 1990. London: C Hurst \& Co.

Wapner, P. 1998. Reorienting state sovereignty: rights and responsibilities in the environmental age. In K. Liftin (ed.). The greening of sovereignty in world politics. Cambridge, MA: MIT Press. Pp. 275297.

Watts, M.J. 2003. Economies of violence. more oil, more blood. Economic and Political Weekly 38(48): 5089-5099.

Weylandt, M. 2017. The Namibian anti-corruption strategy 2016-2019: an overview and analysis. Namibia: Institute for Public Policy Research.

Winder, G. and R. Le Heron. 2017. Assembling a blue economy moment? Geographic engagement with globalizing biological-economic relations in multi-use marine environments. Dialogues in Human Geography 7(1): 3-26.

Winterfeldt, V. 2002. Traditionalism - social reality of a myth. In Winterfeldt, V., T. Fox, and P. Mufune (eds.). Namibia, society, sociology. Windhoek: University of Namibia Press.

World Bank. 2017a. What is the Blue Economy? [accessed August 30 2018]. http://www.worldbank.org/en/news/infographic/2017/06/06/blue-economy.

World Bank. 2017b. Namibia Data Bank [accessed April $10 \quad 2018$ ]. http://www.worldbank.org/en/country/namibia.

World Trade Organisation. 2010. World Trade Report. Trade in natural resources. Switzerland: WTO Publications. 